\title{
Analisis Kualitas Fisika dan Kimia Air di Kawasan Budidaya Perikanan Kabupaten Majalengka
}

\author{
Ligar Novi Ayuniar $^{1)}$, Jafron Wasiq Hidayat ${ }^{2)}$ \\ ${ }^{1)}$ Magister Ilmu Lingkungan, Sekolah Pascasarjana, Universitas Diponegoro \\ ${ }^{2)}$ Jurusan Biologi, Fakultas Sains dan Matematika, Universitas Diponegoro \\ *ligar.novi@gmail.com
}

\begin{abstract}
ABSTRAK
Produksi budidaya ikan sangat dipengaruhi oleh kualitas air, baik itu kualitas air budidaya ataupun kualitas air sumber. Kualitas air yang baik akan memberikan dampak yang positif terhadap ikan yang dipelihara, sedangkan kualitas air yang buruk dapat menyebabkan pertumbuhan ikan tidak optimal dan memberikan dampak yang negatif terhadap ikan yang dipelihara. Penelitian ini bertujuan untuk menganalisis parameter fisika dan kimia perairan di kawasan budidaya perikanan kabupaten majalengka. Parameter yang dianalisis yaitu suhu, pH, DO, fosfat, nitrat, dan BOD. Metode pada penelitian ini yaitu analisis deskriptif. Hasil dari penelitian ini adalah bila dibandingkan dengan PP No. 82 Tahun 2001 parameter suhu dan pH termasuk ke dalam baku mutu kelas II, untuk DO titik ke $1-4$ telah memenuhi baku mutu kelas II sedangkan untuk titik kelima tidak memenuhi baku, untuk fosfat melebihi baku mutu kelas II, untuk nitrat kelima hasil masih dibawah baku mutu, untuk ammonia melebihi baku mutu dan untuk BOD titik 2-4 melebihi baku mutu sedangkan titik 1 dan 5 dibawah baku mutu.
\end{abstract}

\section{Kata Kunci: Kualitas Air, Budidaya Perikanan, Air Tawar}

\section{PENDAHULUAN}

Produksi perikanan budidaya (akuakultur) tumbuh pesat dalam 2-3 dekade terakhir. Budidaya perikanan menyumbang sekitar sepertiga pasokan ikan dunia (Nisa et al., 2015). Indonesia saat ini menjadi salah satu produsen akuakultur utama dunia. Untuk wilayah Asia, produksi akuakultur Indonesia sebanyak 4,32\%, sedangkan di dunia produksi akuakultur Indonesia berkontribusi sebesar 3,85\% atau menempati peringkat ke 4 baik di Asia maupun dunia (FAO, 2014). Berdasarkan data Badan Pusat Statistik bahwa jumlah produksi budidaya ikan di kolam pada tahun 2015 mencapai 2.043.000 ton, sedangkan total produksi perikanan budidaya pada tahun 2015 yaitu sebanyak 15.634.000 ton. Produksi perikanan budidaya berasal dari usaha budidaya laut, budidaya tambak, budidaya kolam, budidaya keramba, budidaya jaring apung, budidaya sawah, dan budidaya laut.

Produksi budidaya perikanan dipengaruhi oleh tiga faktor yaitu kualitas benih, kualitas pakan, dan kualitas air. Benih yang digunakan alangkah baiknya apabila menggunakan benih yang di dapatkan dari pembenihan yang bersertifikat agar mendapatkan kualitas benih yang baik. Pakan merupakan faktor produksi yang menjadi komponen biaya tersebar dalam suatu usaha budidaya ikan. Budidaya ikan memperkaya lingkungan dengan buangan pakan termetabolisir dan yang tidak termakan. Sampai batas waktu tertentu buangan pakan termetabolit tersebut bermanfaat karena meningkatkan produksi ikan, apabila melebihi jumlah tertentu zat tersebut pada akhirnya menjadi pencemar. Kualitas pakan juga dapat berpengaruh terhadap kondisi air. Kualitas air yang baik akan memberikan dampak yang positif terhadap ikan yang dipelihara, sedangkan kualitas air yang buruk dapat menyebabkan pertumbuhan ikan tidak optimal dan memberikan dampak yang negatif terhadap ikan yang dipelihara. Penurunan kuantitas dan kualitas air akan menganggu pertumbuhan dan bahkan menyebabkan infeksi penyakit yang tumbuh dan berkembang dalam perairan yang bermutu tidak baik (Syamsunarno, 2016). Kualitas air yang dimaksud bukan hanya kualitas air media melainkan juga kualitas air sumber. Air sumber bisa berasal dari air sumur ataupun air sungai. Kualitas air sumber yang akan masuk kedalam media budidaya ikan harus mempunyai kualitas yang baik dan belum tercemar, sehingga kita juga perlu menjaga kualitas air sumber. Kualitas air adalah kondisi kualitatif air yang diukur dan diuji berdasarkan parameter tertentu dan 
metode tertentu berdasarkan peraturan perundang-undangan yang berlaku (Kepmen LH No. 115 Tahun 2003).

Kabupaten Majalengka merupakan salah satu Kabupaten yang memiliki potensi dibidang perikanan budidaya, khususnya di perikanan budidaya air tawar. Berdasarkan data Dinas Pertanian dan Perikanan Kabupaten Majalengka, dalam kurun waktu tujuh tahun terakhir (2011-2017) produksi perikanan budidaya tertinggi yaitu terdapat di Kecamatan Talaga dengan total produksi sebesar 4255,60 Ton, diurutan kedua yaitu Kecamatan Sidangwangi dengan total produksi sebesar 4109,56 Ton, dan diurutan ketiga yaitu yaitu Kecamatan Rajagaluh dengan total produksi sebesar 3.309,42 Ton. Jumlah produksi perikanan budidaya terendah yaitu terdapat di Kecamatan Dawuan dengan total produksi sebesar 398,11 Ton, diurutan kedua yaitu Kecamatan Sumberjaya dengan total produksi sebesar 417,60 Ton, dan diurutan ketiga yaitu Kecamatan Kasokandel dengan total produksi sebesar 419,31 Ton, sedangkan untuk produksi ikan tertinggi yaitu produksi ikan nila dengan jumlah produksi sebesar 27.618,03 Ton, urutan kedua yaitu produksi ikan mas dengan jumlah produksi sebesar 11.020,16 Ton dan urutan ketiga yaitu produksi ikan lele dengan jumlah produksi sebesar 10.533,16 Ton. Total produksi untuk ketiga ikan tersebut dalam kurun waktu tujuh tahun yaitu sebesar 49.171,35 Ton. Berdasarkan data diatas peneliti tertarik untuk melakukan penelitian mengenai kualitas air, karena kualitas air berperan penting terhadap produksi perikanan budidaya.

\section{TINJAUAN PUSTAKA}

Suhu atau temperatur pada badan air penerima/sungai dapat berubah karena perubahan musim, perubahan harian dan masukan berupa buangan air limbah yang panas dari industri. Suhu memperlihatkan kecenderungan aktivitas kimiawi dan biologis di dalam air. Perubahan suhu berpengaruh terhadap proses fisika, kimia, dan biologi badan air. Kenaikan suhu air akan menimbulkan beberapa akibat sebagai berikut: jumlah oksigen terlarut di dalam air menurun, kecepatan reaksi kimia meningkat, kehidupan ikan dan hewan air lainnya terganggu dan jika batas suhu yang mematikan terlampaui, ikan dan hewan lainnya mungkin akan mati (Ferdiaz, 1992). Peningkatan suhu juga menyebabkan terjadinya peningkatan dekomposisi bahan organik oleh mikroba. Kisaran suhu optimum bagi pertumbuhan fitoplankton diperairan adalah $20-30^{\circ} \mathrm{C}$ (Effendi, 2003), sedangkan kisaran suhu optimal bagi kehidupan ikan di perairan tropis adalah antara $28^{\circ} \mathrm{C}-32^{\circ} \mathrm{C}$ (Kordi dan Tancung, 2005).

Oksigen terlarut merupakan variabel kualitas air yang paling kritis dalam kegiatan akuakultur (Boyd, 1998). Jumlah oksigen terlarut di air sangat penting bagi organisme akuatik. Hal ini karena oksigen terlarut mempengaruhi pertumbuhan, kelangsungan hidup, distribusi, tingkah laku dan fisiologi organisme akuatik. Ditribusi oksigen juga secara kuat mempengaruhi kelarutan nutrien anorganik. Keberadaan oksigen juga digunakan untuk menentukan apakah lingkungan dalam kondisi aerobik atau anaerobik (Ekubo dan Abowei, 2011). Nilai Do yang biasanya diukur dalam bentuk konsentrasi ini menunjukkan jumlah oksigen $\left(\mathrm{O}_{2}\right)$ yang tersedia dalam suatu badan air. Semakin besar nilai DO pada air, mengindikasikan air tersebut memiliki kualitas yang bagus. Pengukuran DO juga bertujuan melihat sejauh mana badan air mampu menampung biota air seperti ikan dan mikroorganisme.

$\mathrm{pH}$ adalah derajat keasaman yang digunakan untuk menyatakan tingkat keasaman atau kebasaan yang dimiliki oleh suatu larutan. Nilai $\mathrm{pH}$ mempunyai range skala 0 hingga 14. Air dikatakan netral bila mempunyai $\mathrm{pH}$ dengan nilai 7. Artinya larutan atau air mengandung konsentrasi yang seimbang antara ion $\mathrm{H}^{+}$dan $\mathrm{OH}^{-}$. Substansi yang mempunyai $\mathrm{pH}$ kurang dari 7 dikatakan bersifat asam dan mengandung lebih banyak $\mathrm{H}+$ dibandingkan dengan ion $\mathrm{OH}-$. Substansi dengan $\mathrm{pH}$ lebih rendah dikatakan lebih bersifat asam dan substansi dengan $\mathrm{pH}$ lebih dari 7 dikatakan bersifat basa. Nilai pH 7 - 8,5 merupakan kisaran nilai yang ideal untuk produktifitas biologi, sedangkan nilai $\mathrm{pH}$ dibawah 4 akan merugikan bagi kehidupan akuatik. Kebanyakan organisme akuatik tidak menyukai kisaran fluktuasi harian $\mathrm{pH}$ yang lebar karena pada kondisi ini akan berdampak pada kematian organisme. Oleh 
karena itu, air dengan kisaran fluktuasi $\mathrm{pH}$ yang rendah akan lebih mendukung bagi kehidupan akuatik (Ekubo dan Abowei, 2011). Menurut Boyd (1998), pengaruh langsung $\mathrm{pH}$ terhadap ikan dan udang yaitu nilai $\mathrm{pH} 4$ berdampak titik mati asam, nilai pH 4-5 berdampak tidak adanya reproduksi, nilai $\mathrm{pH}$ 6-9 pertumbuhan terbaik, nilai $\mathrm{pH}$ 9-11 dapat menyebabkan pertumbuhan lambat dan untuk nilai $\mathrm{pH} 11$ berdampak titik mati basa. Nilai $\mathrm{pH}$ untuk kebanyakan tambak air tawar antara 6-9 dengan kisaran fluktuasi harian 1 atau 2 unit. Air payau biasanya mempunyai nilai $\mathrm{pH} \quad 8-9$ dan fluktuasi $\mathrm{pH}$ harian biasanya lebih rendah dibandingkan tambak air tawar. Fluktuasi harian $\mathrm{pH}$ dihasilkan dari perubahan tingkat fotosintesis oleh fitoplankton dan tanaman akuatik lainnya dalam merespon fotoperiod harian.

Fosfat merupakan bentuk dari unsur fosfor yang terdapat di dalam air. Berasal dari detergent sisa cucian, kotoran hewan, pupuk yang terlarut, dan lain-lain. Berfungsi sebagai hara untuk tanaman air, dan dapat mengakibatkan proses eutrofikasi (Rahayu, 2009). Kadar fosfor dalam bentuk fosfat untuk kepentingan perikanan tidak boleh lebih dari 0,2 mg/l (Baku Mutu Kelas II PP Nomor 82 Tahun 2001 tentang Pengelolaan Kualitas Air dan Pengendalian Pencemaran Air). Fosfat dalam perairan adalah dalam bentuk bentuk orthofosfat $\left(\mathrm{PO}_{4}\right)$, kandungan orthofosfat dalam air merupakan karakteristik kesuburan perairan tersebut. Perairan yang mengandung orthofosfat antara 0,003-0,010 mg/L merupakan perairan yang oligotrofik, 0,01-0,03 adalah mesotrofik dan 0,03-0,1 $\mathrm{mg} / \mathrm{L}$ adalah eutrofik. (Jollenweider, 1968, dalam Mustofa, 2015).

Nitrat mewakili hasil akhir degradasi bahan organik (nitrogen), nitrat berasal dari limbah domestik, sisa pupuk pertanian, atau dari nitrit yang mengalami proses nitrifikasi. Nitrat dapat menyebabkan pencemaran karena dapat menimbulkan eutrofikasi sehingga mengurangi jumlah oksigen terlarut dan menaikkan BOD5. Limbah yang dibenahi secara efisien akan menunjukkan kandungan nitrat yang tinggi (Damanik, 2011). Perairan yang mengandung nitrat dengan kisaran $0-1 \mathrm{mg} / \mathrm{L}$ termasuk perairan oligotropik, 1-5 mg/L adalah mesotrofik dan $5-50 \mathrm{mg} / \mathrm{L}$ adalah eutrofik (Jollenweider, 1968 dalam Mustofa, 2015). Nitrat adalah unsur yang penting dalam fotosintesis tanaman air. Orang dewasa mempunyai toleransi tinggi untuk ion nitrat, tetapi untuk bayi dan binatang memamah biak ion tersebut bersifat toksik. Dalam sistem pencernaan dari bayi dan binatang memamah biak, nitrat direduksi nitrit. Nitrit dapat mengikat hemoglobin dalam darah (Rukaesih, 2004).

Sumber amonia di perairan berasal dari pemecahan nitrogen organik (protein dan urea) dan nitrogen anorganik yang terdapat dalam tanah dan air dan berasal dari dekomposisi bahan organik (tumbuhan dan biota akuatik yang telah mati) oleh mikroba dan jamur. Tinja dan ekskresi biota akuatik merupakan limbah dari aktivitas metabolisme yang menghasilkan amonia. Kadar amonia pada perairan alami biasanya kurang dari $0,1 \mathrm{mg} / \mathrm{L}$. Kadar amonia yang tinggi mengindikasikan adanya pencemaran bahan organik yang berasal dari limbah domestik, industri dan limpasan pupuk pertanian (Effendi, 2000).

Kebutuhan oksigen biokimia (Biochemiycal Oxygen Demand disingkat BOD) adalah suatu karakteristik yang menunjukkan jumlah oksigen terlarut yang diperlukan mikroorganisme untuk mengurai atau mendekomposisi bahan organik dalam kondisi aerobik. Proses oksidasi biokimia ini berjalan sangat lambat dan dianggap lengkap (95-96\%) selama 20 hari. Tetapi penentuan BOD selama 20 hari dianggap masih cukup lama sehingga penentuan BOD ditetapkan selama 5 hari inkubasi, maka biasa disebut BOD5 (APHA, AWWA, WEF, 2012). BOD tidak menunjukkan jumlah bahan organik yang sebenarnya, tetapi hanya mengukur secara relatif jumlah $\mathrm{O}_{2}$ yang dibutuhkan untuk mengoksidasi bahan-bahan buangan tersebut. Jika konsumsi $\mathrm{O}_{2}$ tinggi yang ditunjukkan dengan semakin kecilnya $\mathrm{O}_{2}$ terlarut, maka kandungan bahan-bahan buangan yang membutuhkan $\mathrm{O}_{2}$ tinggi. Semakin besar kadar BOD, maka merupakan indikasi bahwa perairan tersebut telah tercemar (Ferdiaz, 1992). Kadar BOD dalam air yang tingkat pencemarannya masih rendah dan dapat dikatagorikan sebagai perairan yang baik berkisar $0-10 \mathrm{mg} / \mathrm{L}$ (Salmin, 2005 dalam Yuliastuti, 2011). 


\section{METODE}

Penelitian ini menggunakan metode analisis deskriptif. Penelitian ini dilakukan di lima titik sampling, yaitu 1 titik di sungai sebelum kolam budidaya, 3 titik di kawasan kolam budidaya dan 1 titik di sungai setelah kolam budidaya. Parameter yang dianalisis yaitu suhu, $\mathrm{pH}, \mathrm{DO}$, fosfat, nitrat, nitrit, dan BOD. Untuk parameter suhu, $\mathrm{pH}, \mathrm{DO}$ diuji secara insitu yaitu menggunakan water quality checker, sedangkan untuk parameter fosfat, nitrat, nitrit, dan BOD dilakukan di Laboratorium Pengelolaan Sumberdaya Ikan dan Lingkungan, Departemen Sumberdaya Akuatik, Fakultas Perikanan dan Ilmu Kelautan, Universitas Diponegoro.

\section{HASIL DAN PEMBAHASAN}

Tabel 1. Hasil Penelitian

\begin{tabular}{|c|c|c|c|c|c|c|}
\hline $\begin{array}{c}\text { Para } \\
\text { mete } \\
\text { r }\end{array}$ & $\begin{array}{c}\mathbf{T i} \\
\text { tik } \\
\mathbf{1}\end{array}$ & $\begin{array}{c}\text { Ti } \\
\text { tik } \\
2\end{array}$ & $\begin{array}{c}\mathbf{T i} \\
\text { tik } \\
3\end{array}$ & $\begin{array}{c}\text { Ti } \\
\text { tik } \\
4\end{array}$ & $\begin{array}{c}\text { Ti } \\
\text { tik } \\
5\end{array}$ & $\begin{array}{c}\text { PP } \\
\text { No. } \\
82 \\
\text { Tahu } \\
\text { n } \\
\text { 2001 } \\
\text { Baku } \\
\text { Mutu } \\
\text { Kelas } \\
\text { II }\end{array}$ \\
\hline $\begin{array}{l}\text { Suhu } \\
\left({ }^{\circ} \mathrm{C}\right)\end{array}$ & $\begin{array}{r}28 \\
, 4\end{array}$ & $\begin{array}{l}28 \\
, 4 \\
5\end{array}$ & $\begin{array}{r}28 \\
9\end{array}$ & $\begin{array}{l}29 \\
, 1 \\
5\end{array}$ & $\begin{array}{c}29 \\
, 9 \\
3\end{array}$ & $\begin{array}{c}\text { Devia } \\
\text { si } 3 \\
\text { dari } \\
\text { alami } \\
\text { ahnya }\end{array}$ \\
\hline $\begin{array}{c}\text { Do } \\
(\mathrm{mg} / \mathrm{l} \\
)\end{array}$ & $\begin{array}{l}6, \\
82\end{array}$ & $\begin{array}{l}6, \\
35\end{array}$ & $\begin{array}{l}7, \\
19\end{array}$ & $\begin{array}{l}6, \\
43\end{array}$ & $\begin{array}{l}2, \\
34\end{array}$ & 4 \\
\hline $\mathrm{pH}$ & $\begin{array}{l}7, \\
69\end{array}$ & $\begin{array}{l}7, \\
65\end{array}$ & $\begin{array}{l}7, \\
73\end{array}$ & $\begin{array}{l}7, \\
71\end{array}$ & $\begin{array}{l}7, \\
98\end{array}$ & $6 \mathrm{sd} 9$ \\
\hline $\begin{array}{c}\text { Fosfa } \\
t \\
(\mathrm{mg} / \mathrm{l} \\
)\end{array}$ & $\begin{array}{c}0, \\
44 \\
8\end{array}$ & $\begin{array}{c}1, \\
03 \\
3\end{array}$ & $\begin{array}{c}1, \\
05 \\
3\end{array}$ & $\begin{array}{c}0, \\
42 \\
9\end{array}$ & $\begin{array}{l}0, \\
44\end{array}$ & 0,2 \\
\hline $\begin{array}{c}\text { Nitrat } \\
(\mathrm{mg} / \mathrm{l} \\
)\end{array}$ & $\begin{array}{c}2, \\
65 \\
9\end{array}$ & $\begin{array}{l}3, \\
21\end{array}$ & $\begin{array}{c}2, \\
69 \\
3\end{array}$ & $\begin{array}{c}2, \\
62 \\
4\end{array}$ & $\begin{array}{c}3, \\
72 \\
8\end{array}$ & 10 \\
\hline $\begin{array}{c}\text { Amm } \\
\text { onia } \\
(\mathrm{mg} / \mathrm{l} \\
\text { ) }\end{array}$ & $\begin{array}{c}0, \\
16 \\
7\end{array}$ & $\begin{array}{c}2, \\
30 \\
9\end{array}$ & $\begin{array}{c}2, \\
07 \\
8\end{array}$ & $\begin{array}{c}0, \\
09 \\
4\end{array}$ & $\begin{array}{c}0, \\
23 \\
3\end{array}$ & 0,02 \\
\hline $\begin{array}{c}\mathrm{BOD} \\
(\mathrm{mg} / \mathrm{l} \\
)\end{array}$ & $\begin{array}{c}0 \\
4\end{array}$ & $\begin{array}{l}3, \\
8\end{array}$ & $\begin{array}{l}7, \\
6\end{array}$ & $\begin{array}{l}4 \\
4\end{array}$ & $\begin{array}{l}1, \\
6\end{array}$ & 3 \\
\hline
\end{tabular}

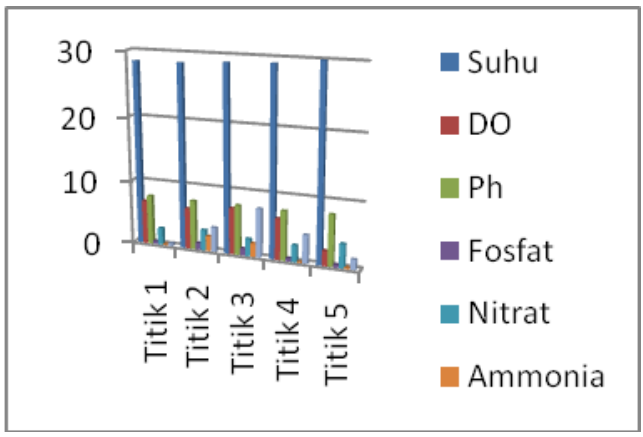

\section{Grafik Hasil Penelitian}

Suhu

Hasil pengujian suhu di lapangan pada titik kesatu yaitu $28,4^{\circ} \mathrm{C}$, titik kedua yaitu $28,45^{\circ} \mathrm{C}$, titik ketiga yaitu $28,9^{\circ} \mathrm{C}$, titik keempat yaitu $29,15^{\circ} \mathrm{C}$, dan titik kelima yaitu $29,93^{\circ} \mathrm{C}$. Bila dibandingkan dengan baku mutu kelas II PP No. 82 Tahun 2001, maka nilai suhu yang didapatkan dalam penelitian ini masih tergolong baik untuk kehidupan ikan di perairan tropis. Hal ini juga sesuai dengan pendapat Kordi dan Tancung (2005) bahwa kisaran suhu optimal bagi kehidupan ikan di perairan tropis adalah antara $28^{\circ} \mathrm{C}-32^{\circ} \mathrm{C}$. Suhu memiliki peran yang penting untuk kehidupan ikan di perairan, hal ini sesuai dengan pendapat Taufik, Azwar, dan Sutrisno (2009) bahwa suhu air merupakan salah satu komponen penting yaitu sebagai controling factor yang dapat mempengaruhi sintasan organisme air. Ikan merupakan hewan berdarah dingin (poikilothermal), sehingga proses metabolisme maupun kekebalan tubuhnya sangat tergantung pada suhu lingkungan.

DO

Hasil pengujian DO di lapangan pada titik kesatu yaitu $6,82(\mathrm{mg} / \mathrm{l})$, titik kedua yaitu $6,35(\mathrm{mg} / \mathrm{l})$, titik ketiga yaitu 7,19 (mg/l), titik keempat yaitu 6,43 (mg/l), dan titik kelima yaitu 2,34 (mg/l). Berdasarkan baku mutu kelas II PP No. 82 Tahun 2001 bahwa nilai minimal DO yaitu 4 (mg/l), maka untuk titik ke $1-4$ telah memenuhi baku mutu kelas II, sedangkan untuk titik kelima tidak memenuhi baku mutu kelas II, hal ini menandakan bahwa perairan tersebut tidak baik untuk keberlangsungan hidup organisme akuatik. Pendapat ini sesuai dengan penelitian yang dilakukan Suminar (2010) dalam Sumantry (2012) mengatakan bahwa kadar oksigen 
kurang dari $4 \mathrm{mg} / \mathrm{l}$ akan menimbulkan efek yang kurang menguntungkan bagi hampir semua mikroorganisme akuatik dan kadar oksigen kurang dari $2 \mathrm{mg} / \mathrm{l}$ dapat mengakibatkan kematian ikan. Sedangkan untuk titik 1 - 4 merupakan nilai yang sesuai untuk keberlangsungan hidup organisme akuatik, hal ini sesuai dengan pendapat Boyd (1998) bahwa konsentrasi oksigen terlarut $5 \mathrm{mg} / \mathrm{l}$ - saturasi yaitu merupakan kondisi yang terbaik untuk pertumbuhan, sedangkan konsentrasi oksigen terlarut diatas saturasi dapat membahayakan jika kondisi supersaturasi terjadi pada seluruh volume kolam.

\section{pH}

Hasil pengujian $\mathrm{pH}$ di lapangan pada titik kesatu yaitu 7,69, titik kedua yaitu 7,65 , titik ketiga yaitu 7,73 , titik keempat yaitu 7,71, dan titik kelima yaitu 7,98.

Dari kelima titik tersebut bila dibandingkan dengan PP No. 82 Tahun 2001 maka telah memenuhi baku mutu kelas II yaitu nilai antara $6-9$. Berdasarkan hasil dari kelima titik menandakan bahwa nilai $\mathrm{pH}$ sesuai untuk kehidupan organisme akuatik. Hal ini sesuai dengan pendapat Ekubo dan Abowei (2011), bahwa nilai pH 7 - 8,5 merupakan kisaran nilai yang ideal untuk produktifitas biologi, sedangkan nilai pH dibawah 4 akan merugikan bagi kehidupan akuatik. Kebanyakan organisme akuatik tidak menyukai kisaran fluktuasi harian $\mathrm{pH}$ yang lebar karena pada kondisi ini akan berdampak pada kematian organisme. Oleh karena itu, air dengan kisaran fluktuasi $\mathrm{pH}$ yang rendah akan lebih mendukung bagi kehidupan akuatik.

\section{Fosfat}

Berdasarkan pengujian fosfat di laboratorium menunjukan hasil pada titik kesatu yaitu $0,448 \mathrm{mg} / \mathrm{l}$, titik kedua yaitu $1,033 \mathrm{mg} / \mathrm{l}$, titik ketiga yaitu $1,053 \mathrm{mg} / \mathrm{l}$, titik keempat yaitu $0,429 \mathrm{mg} / \mathrm{l}$, dan titik kelima yaitu $0,44 \mathrm{mg} / \mathrm{l}$. Kelima nilai tersebut telah melebihi baku mutu kelas II yang ditentukan oleh PP No. 82 Tahun 2001 yaitu senilai 0,2. Hal ini bisa disebabkan karena adanya limbah di perairan, sisa pakan, feses dan ikan yang mati di perairan. Hal ini sesuai dengan pendapat Fachriza, Yusni dan Nurmatias (2015) mengatakan bahwa adanya unsur hara di terjadi akibat dari akumulasi sisa pakan yang terbuang, feces dan ikan yang mati dari aktifitas budidaya ikan.

\section{Nitrat}

Berdasarkan pengujian nitrat di laboratorium menunjukan hasil pada titik kesatu yaitu 2,659 mg/l, titik kedua yaitu $3,21 \mathrm{mg} / \mathrm{l}$, titik ketiga yaitu $2,693 \mathrm{mg} / \mathrm{l}$, titik keempat yaitu 2,624 mg/l, dan titik kelima yaitu 3,728 mg/l. Kelima hasil tersebut masih dibawah baku mutu yang ditentukan oleh PP No. 82 Tahun 2001 bahwa baku mutu nitrat kelas II yaitu $10 \mathrm{mg} / \mathrm{l}$. Nitrat dapat digunakan untuk mengklasifikasikan kesuburan perairan. Hal ini sesuai dengan yang dikemukakan oleh Jollenweider (1968) dalam Mustofa (2015) bahwa perairan yang mengandung nitrat dengan kisaran $0-1 \mathrm{mg} / \mathrm{L}$ termasuk perairan oligotropik, 1-5 $\mathrm{mg} / \mathrm{L}$ adalah mesotrofik dan 5-50 mg/L adalah eutrofik. Nitrat yang terlalu tinggi dapat menyebabkan eutrifikasi perairan yang nantinya dapat berakibat alga blooming. Menurut Nurlita dan Utomo (2011), unsurunsur nitrogen seperti $\mathrm{NH}_{4}, \mathrm{NO}_{3}$, dan $\mathrm{NO}_{2}$ dapat menyebabkan eutrofikasi. Peristiwa eutrofikasi ini dapat menyebabkan suatu kondisi yang disebut dengan alga blooming dikarenakan terlalu banyak unsur hara untuk menghasilkan alga tersebut. Eutrofikasi ini dapat dikatakan merusak ekosistem sekitarnya karena supply oksigen yang berada di perairan tersebut berkurang atau bahkan dikatakan tidak ada, dan pada akhirnya dapat mengganggu proses kehidupan di perairan.

\section{Ammonia}

Berdasarkan pengujian ammonia di laboratorium menunjukan hasil pada titik kesatu yaitu $0,167 \mathrm{mg} / \mathrm{l}$, titik kedua yaitu 2,309 mg/l, titik ketiga yaitu 2,078 mg/l, titik keempat yaitu 0,094 mg/l, dan titik kelima yaitu $0,233 \mathrm{mg} / \mathrm{l}$. Bila dibandingkan dengan PP No. 82 Tahun 2001 maka nilai kelima ammonia tersebut telah melewati baku mutu kelas II yang digunakan untuk baku mutu budidaya ikan air tawar yaitu $0,02 \mathrm{mg} / \mathrm{l}$. Tingginya nilai ammonia disebabkan oleh adanya sisa pakan dan feses di perairan. Hal ini sesuai dengan yang dikemukakan oleh Efendi (2003) dalam Marlina dan Rakhmawati (2016) bahwa limbah budidaya ikan yang merupakan hasil aktivitas metabolisme banyak mengandung amonia. 
Ammonia juga dapat menjadi penyebab turunnya kualitas suatu perairan, khususnya perairan yang digunakan untuk budidaya perikanan. Hal ini sesuai dengan yang dikemukakan oleh Wijaya et. al. (2014) bahwa akumulasi amonia pada media budidaya merupakan salah satu penyebab penurunan kualitas perairan yang dapat berakibat pada kegagalan produksi budidaya ikan.

\section{BOD}

Berdasarkan pengujian BOD di laboratorium menunjukan hasil pada titik kesatu yaitu 0,4 mg/l, titik kedua yaitu 3,8 $\mathrm{mg} / \mathrm{l}$, titik ketiga yaitu 7,6 mg/l, titik keempat yaitu 4,4 mg/l, dan titik kelima yaitu 1,6 mg/l. Bila dibandingkan dengan PP No. 82 Tahun 2001 maka nilai BOD yang melewati baku mutu yaitu terdapat pada titik kedua, ketiga dan keempat dengan baku mutu BOD kelas II yaitu 3 mg/l. BOD tinggi menunjukkan bahwa jumlah oksigen yang dibutuhkan oleh mikroorganisme untuk mengoksidasi bahan organik dalam air tersebut tinggi, hal berarti dalam air sudah terjadi defisit oksigen. Banyaknya mikroorganisme yang tumbuh dalam air disebabkan banyaknya makanan yang tersedia (bahan organik), oleh karena itu secara tidak langsung BOD selalu dikaitkan dengan kadar bahan organik dalam air (Tatangindatu et al., 2013).

\section{KESIMPULAN}

Kesimpulan yang dapat diambil pada penelitian ini yaitu untuk parameter fisika dan kimia perairan di kawasan budidaya perikanan Kabupaten Majalengka terdapat beberapa parameter yang dibawah baku mutu kelas II PP No. 82 Tahun 2001 ataupun diatas baku mutu kelas II, diantaranya adalah parameter suhu dan $\mathrm{pH}$ termasuk ke dalam baku mutu kelas II, untuk DO titik ke $1-4$ telah memenuhi baku mutu kelas II sedangkan untuk titik kelima tidak memenuhi baku, untuk fosfat melebihi baku mutu kelas II, untuk nitrat kelima hasil masih dibawah baku mutu, untuk ammonia melebihi baku mutu dan untuk BOD titik 2-4 melebihi baku mutu sedangkan titik 1 dan 5 dibawah baku mutu.

\section{DAFTAR PUSTAKA}

APHA, AWWA, WEF. 2012. Standard Methods for Examination of Water and Wastewater. 22nd ed. Washington: American Public Health Association; 2012, 1360 pp. ISBN 978-087553-0130.

Boyd, C.E., L. Massaut, and L.J.Weddig, 1998. Towards reducing environmental impacts of pond aquaculture. INFOFISH Internasional 2/98, p : 27 33.

Damanik, M.M.B., B.E. Hasibuan., Fauzi., Sarifuddin., dan H. Hanum. 2011. Kesuburan Tanah dan Pemupukan. USU Press, Medan.

Effendi, H. 2000. Telaahan Kualitas Air bagi Pengelolaan Sumberdaya dan Lingkungan Perairan. Institut Pertanian Bogor Press., Bogor.

Effendi, H. 2003. Telaah Kualitas Air : Bagi Pengelolaan Sumber Daya dan Lingkungan Perairan. Penerbit KANISIUS. Yogyakarta.

Ekubo, A. A., \& J. F. N. Abowei., (2011). Review of Some Water Quality Management Principles in Culture Fisheries. Research Journal of Applied Sciences, Engineering Technology, 3(12), 1342-1357. Retrieved from http://maxwellsci.com/

Fachriza , Fikri., E. Yusni., dan Nurmatias. 2015. Analisis Kandungan Fosfor Terhadap Daya Dukung Perairan Danau Lut Tawar Untuk Budidaya Sistem Keramba Jaring Apung. Program Studi Manajemen Sumberdaya Perairan, Fakultas Pertanian, Universitas Sumatera Utara.

Fardiaz, S.1992. Polusi dan Udara. Penerbit Kanisius. Yogyakarta.

Keputusan Menteri Negara lingkungan Hidup Nomor 115 Tahun 2003 tentang Pedoman Penentuan Status Mutu Air

Kordi, M. G. H.., dan A. B. Tancung. (2005). Pengelolaan Kualitas Air dalam Budidaya Perairan. Publisher Rineka Cipta. Jakarta.

Mustofa, A. 2015. Kandungan Nitrat Dan Pospat Sebagai Faktor Tingkat Kesuburan Perairan Pantai. Jurnal DISPROTEK Volume 6 no. 1. Hal 1319. 
Nisa, K., Z. Nasution., K.E.L Ramija., 2015. Studi Kualitas Perairan Sebagai Alternatif Pengembangan Budidaya Ikan di Sungai Keureuto Kecamatan Lhoksukon Kabupaten Aceh Utara Provinsi Nanggroe Aceh Darussalam. Universitas Sumatera Utara.

Nurlita, H dan Sudarno U. 2011. Potensi Nitrikasi Oleh Bakteri yang Terdapat di Laut Aliran Kali Plumbon, Laut Aliran Kali Banjir Kanal Barat dan Laut Aliran Kali Banjir Kanal Timur. Jurnal Presipitasi. VIII (1):187-198.

Peraturan Pemerintah Nomor 82 Tahun 2001 tentang Pengelolaan Kualitas Air dan Pengendalian Pencemaran Air

Rahayu, S., R.H.Widodo., M. van Noordwijk., I. Suryadi dan B. Verbist. 2009. Monitoring air di daerah aliran sungai. Bogor, Indonesia. World Agroforestry Centre - Southeast Asia Regional Office. 104 p.

Rukaesih, A. 2004. Kimia Lingkungan. Yogyakarta: Penerbit ANDI.

Sumantry, T. 2012. Pengukuran Debit Dan Kualitas Air Sungai Cisalak Pada Tahun 2012. Pusat Teknologi Limbah Radioaktif - Batan. Hasil Penelitian Dan Kegiatan PTLR Tahun 2012.

Syamsunarno, M. B., dan M.T. Sunarno. 2016. Budidaya Ikan Air Tawar Ramah Lingkungan Untuk Mendukung Keberlanjutan Penyediaan Ikan Bagi Masyarakat. Seminar Nasional Perikanan Dan Kelautan. Pembangunan Perikanan Dan Kelautan Dalam Mendukung Kedaulatan Pangan Nasional. Bandar Lampung. Hal 1-15.

Taufik, Imam., I. Azwar., dan Sutrisno. 2009. Pengaruh Perbedaan Suhu Air Pada Pemeliharaan Benih Ikan Betutu (Oxyeleotris Marmorata Blkr) Dengan Sistem Resirkulasi. J. Ris. Akuakultur Vol. 4 No. 3, Desember 2009: 319-325.

Tatangindatu, Frits., O. Kalesaran., R. Rompas. 2013. Studi Parameter Fisika Kimia Air pada Areal Budidaya Ikan di Danau Tondano, Desa Paleloan, Kabupaten Minahasa. Budidaya Perairan Mei 2013 Vol. 1 No. 2 : 8-19

Wijaya O, Raharjo Setya B,Prayogo. 2014. Pengaruh Padat Tebar Ikan Lele Terhadap Laju Pertumbuhan dan Survival Rate Pada Sistem Akuaponik.
Jurnal Ilmiah Perikanan dan Kelautan Vol. 6 No. 1, April 2014

Yuliastuti, Etik. 2011. Kajian Kualitas Air Sungai Ngringo dalam Upaya Pengendalian Pencemaran Air. Tesis. Universitas Diponegoro. Semarang. 